\title{
Promoting Library Services in a Google World
}

\author{
Janine Schmidt, Trenholme Director of Libraries, McGill University, Montreal, Canada
}

\begin{abstract}
As the younger generation of born digital library users and even well-established scholars rely increasingly on Google, or its new products Google Scholar and Google Book, for information resource discovery and access, libraries are finding it increasingly difficult to ensure that their own well structured websites and information services are being utilized appropriately. This paper highlights some of the changes occurring in the information environment and suggests ways of marketing library services effectively to today's users. Marketing concepts are explored, focusing on a clear understanding of users, the library's products, the appropriate place for service delivery, an appropriate pricing strategy - and effective promotional strategies. Promotional strategies which are being used effectively by some commercial organizations, as well as approaches being developed by some libraries, are highlighted. Practical hints are provided so that libraries can ensure that their missions of ensuring that every book has its reader can be accomplished in a new age of access to information in real books and journals and virtual books and journals and other information resources. Libraries no longer operate in a "come and get it" environment and new ways of outreach are described, to ensure that librarians are out amongst their communities, creating an awareness of the services available and ensuring effective use of resources through a variety of approaches used in university libraries in Australia and at McGill University in Montreal, Canada.
\end{abstract}

Keywords: Google. Promotion, Marketing,Libraries

Type of paper. Viewpoint 


\section{The Library Context}

Today's environment has brought with it an increased availability of information and communication technology, new formats of information resources, and in particular the growth of the internet. The information landscape has changed fundamentally. Knowledge is available at one's fingertips via the internet. Online markets are being influenced by E-bay and Amazon as well as the free search engines like Google, Google Book and Google Scholar, which are all transforming resource discovery and information access. The word "google" has become a verb, although the Google organization itself prefers the phrase "to conduct a google search". There will no doubt be future influences from further services like Microsoft's new search engine. RSS (Really Simple Syndication) and RDF (Resource Description Framework) together with the semantic web and the semantic grid are also impacting on the information environment. Blogs and wikis are maturing with stabilized articles and proper editorials and are impacting on traditional publishing. There has been slow acceptance of open access options (including PLOS (Public Library of Science) $)^{1}$, BioMed Central ${ }^{2}$, Oxford $\mathrm{Open}^{3}$ and Blackwell Publishing's Online $\mathrm{Open}^{4}$ ) and institutional repositories are under-populated but they too are gradually transforming information storage and access. Productivity tools to enhance online information are being produced, as well as clinical decision support systems, particularly in evidence based medicine. The existing world of published information continues to grow although print formats, particularly in disciplines related to science, technology and medicine, are converting to electronic formats. Websites are bringing together wide ranges of visual and aural media previously unknown or inaccessible, with sites like FlickR ${ }^{5}$ and YouTube ${ }^{6}$. Memory sticks, wireless, PDAs, iPods, Blackberries, the new Sony e-book ${ }^{7}$ and mobile phones are widening online access and changing the nature of use. While some see the changes as the end of print ${ }^{8}$, most see that there are multiple approaches to information in many formats. The world of data, digital information and traditional formats of information, is vast and finding the pearls of wisdom and knowledge is becoming increasingly difficult. Libraries continue to invest energy in resource discovery and access mechanisms to ensure effective delivery of information, although content management systems and exploitation of metadata and use of XML are leading to alternative innovative discovery and access approaches. Collaboration and cooperation are being emphasised as a new balance is found in the information ecosystem.

The learning environment is multidisciplinary. Combinations of study such as: physics and music; history and mathematics; engineering and biology are becoming more common-place. Research themes are changing. Disciplinary boundaries are blurring and faculties are working collaboratively. Skills are being transferred across disciplines as the growing areas of bioscience, bioengineering and mathematical modeling show. There has also been an increased emphasis on the role of the learner in the educational process and learner-centred teaching, problem and enquiry-based learning and resource discovery learning are pedagogical approaches now in use. The role of the expert is changing. ${ }^{9}$ A wiki university is being developed $^{10}$. Learning has always been a social experience and learners learn from one another, from formal teachers and from life itself. They learn in both formal and informal settings, in the classroom and the laboratory and outside of it - on the playing field, in cafes and in the library. Learning has become any pace, any space and any time and just in case and just in time approaches to learning are becoming personalised, just for you.

The 2003 OCLC Environmental Scan: Pattern Recognition report was produced for OCLC's worldwide membership to examine the significant issues and trends impacting on libraries, museums, archives and other allied organizations, both now and in the future. The scan provides a high-level view of the information landscape, intended both to inform and stimulate discussion about future strategic directions.

${ }^{11}$ The paradigm shifts occurring in information transmission, pedagogy and research activity are transforming the role of the library in teaching, learning and research and have profound implications for both the way the Library delivers and the way it organizes itself. A second OCLC report in 2005 further highlighted the changes occurring in libraries.

The findings indicate that information consumers view libraries as places to borrow print books, but they are unaware of the rich electronic content they can access through libraries. Even though information consumers make limited use of these resources, they continue to trust libraries as reliable sources of information. ${ }^{12}$ 


\section{Today's Library Users}

The clients of libraries can be segmented in marketing terms in various ways. Examining users by age, profession, field of study, type of work, specific need, educational level, lifestyle, amongst many others, all help libraries understand their users and the services they need. The users of today, particularly young people, are accessing and using information very differently. Young people rely more on their friends with single-parent households and fewer siblings at home. Many young people have large amounts of ready cash available. They are "savvy" and demanding. They expect integration of digital content. They live media-saturated lives and use the internet more than they watch television. They use portable devices and access information from their homes, from bars, indeed anywhere. They think they can find all knowledge via Google. The Wikipedia provides free knowledge on every topic and young people are not concerned about the source of the information they find. Blogs tell them that their opinions and thoughts are valuable and that someone somewhere cares about what they have to say.

For young people in Canada, internet usage now surpasses TV viewing. Young people multi-task and use media simultaneously. Time online does not however take away necessarily from real-world activities but enhances them. Today's millennials download various content, ranging from MP3s and music to TV commercials. Young people use free e-mail accounts, frequently using addresses which indicate something personally about them. Over $90 \%$ of young people in Canada use messenger services, customise them and leave them open whenever they are online, although there are significant gender and cultural differences in access and use information.

As young people grow older, they use search engines more for school and work and less for fun and games. Blogging and pod casts are growing in use with $13 \%$ of young people having their own blogs, and $7 \%$ having pod casts. Playing virtual games continually has led to virtual friends in games becoming more important than friends made in real life. Web communities are created using sources like Friendster and Myspace. Music is one of the most common unifiers of youth culture ${ }^{13}$. Providing library and information services to this new generation is challenging. The Pew internet studies have shown that students are moving faster along the curve of technology than faculty and librarians and many students are critical of faculty failures. Computer laboratories remain important for use. $24 \%$ of students surveyed used the internet more than 25 hours each week but were experiencing difficulty in differentiating the quality of information found ${ }^{14}$.

Older users are also changing in their use of libraries. They lead complex lives and are relatively materialistic. Many live alone or in small households and they use the internet for travel, health, recipes and learning. Gender differences are also apparent. Family communication via email is important, particularly for females. Many older users send jokes and store and manipulate music and photographs online. Clearly, more skills are required for everyone in the use of information and communications technology.

\section{What Do Today's Library Users Want?}

Library users continue to want basic services - competence, reliability, responsiveness, timeliness, honesty and a caring approach. They want assistance with information access. They want to read materials - both in print and online formats. They want everything to function effectively and they want help to ensure they use resources effectively - but they want to use self-service approaches as much as possible. They want training and motivation in resource discovery, ICT skills and equitable service delivery. They want answers to questions and solutions to problems. Users want information brought to them and they want services with minimal effort and timeliness. They want just in time service, just for me.

Library users are still visiting libraries. Attendance in most libraries is increasing. However in many Western countries, inquiries made and loans are decreasing. Users want appropriate facilities when they come and complain about poor facilities. The social experience is extremely important. They also want access to computers as well as printers and accompanying services which add value. Libraries have much to learn from shops, restaurants, and internet cafes. Express workstations for quick use and additional facilities for long-term use are both required. 
Remote use of libraries has increased enormously. As tens of thousands of e-journals and e-books become available and are accessed from home, school or work, the type of use made is changing dramatically. How do we know what users want? Libraries must ask users what they want and then listen to what they say. It is also important to observe what users do. Many libraries undertake surveys of their clients. It is vital to respond to concerns raised and to take action to implement changes. Suggestion boxes both physically in the library and on the website will help find out what users want. There is frequently a significant gap between what library staff think users want and what they really want.

In considering what actions to take to respond to both the changes library context and the new approaches by users, some may ask if there is a problem in the library's existing strategies.

If we approach the written word primarily through search-and-seizure rather than sustained encounter-and-contemplation, we risk losing a critical element of what it means to be an educated, literate society. ${ }^{15}$

Libraries have a responsibility to contribute to the growth of an educated literate society and to ensure that their services are well-known and well-used. Libraries must promote themselves effectively. Ranganathan's Five Laws still apply - Every book does have its reader but the Library is a growing and changing organism ${ }^{16}$.

\section{Marketing the Library}

Much has been written on marketing the library ${ }^{17}$. The focus of all service delivery must be on the people being served. Libraries need to consider the real nature of the products they provide - not just books or spaces but life solutions and experiences. Traditional library services must change to accommodate new kinds of users and new kinds of use. New products are being developed. Money may not change hands in library service delivery but all library use involves an investment of time and effort and reflection on the "price" being paid by library users is important. Many libraries are quite difficult and time-consuming to use. Promoting the service is a vital component of service delivery. Many libraries have wonderful services and products but users are unaware of their availability. Branding and badging are terms being used by libraries to ensure that services are marketed effectively. The place where service is provided is vital and service delivery may be one-on-one in person or online to remote users. Libraries in responding to new user needs must think innovatively, plan strategically, develop new products, improve their facilities and market and promote the products provided, the physical places of service delivery and the cyberspace where services are available via the internet.

\section{Product Development}

If one understands users and their requirements, then new products are probably required. Products provided by services organizations like libraries include services. New products or services could relate more to the heavy use of iPods or mobile phone messaging systems. Providing information targeted for downloading to IPods or to mobile/cell telephones is a new requirement. Some libraries are using IPods for making their electronic reserves available and recent work has identified a variety of library applications ${ }^{18}$. Some libraries are lending IPods. Others are delivering services via mobile phones or PDAs. The current generation of library users wants their information available in one place at the one time. Cataloguing rules more appropriate to a card catalogue environment are changing slowly in response to new needs. Some libraries are integrating access via disciplinary and subject gateways. Information literacy programs are being provided interactively for individual and personal use. Perhaps library products are now downloadable video clips, online galleries, subject guides, gateways and links to websites. Online chat is a comparatively new product, provided frequently in partnership with others with services marketed as Askalibrarian. The key messages in marketing such programs should relate to saving time, doing well in study, solving problems and succeeding in life.

\section{Badging the Library}

A key promotional strategy of commercial organisations is branding and badging. The use of logos, unique selling propositions, and slogans has been adopted in advertising and service delivery. The five overlapping circles with their distinctive colours badge the Olympic Games, although each Games adds a local symbol and theme. Throughout the world, the golden arches of McDonalds have become universal, although there are local adjustments, with the maple leaf in red in the centre of the " $m$ " in Canada and "i'm lovin" it" in 
both English and Mandarin in China. Signage, letterhead and publications are all part of the branding used. Libraries have learned from many of these ideas and developed their own form of branding. Some libraries use name badges for their staff, logos, uniforms and publications with the same look and feel. Libraries are badging databases and e-resources purchased from various sources as being delivered by the libraries and are also including messages, unique selling propositions and common images on their websites.

The library brand is not the same today as it was yesterday. The library brand involved keeping books, storing materials, seating readers, accommodating staff and servicing people from desks. The library was frequently an edifice, difficult to use and lacking in functionality. The library constituted a knowledge store and the librarian's adage was come and get it. The library brand of today is a gateway to real and virtual resources, involving cyberspace and physical space, storing materials and computers and providing in-person and online help. It is attractive welcoming, easy to use, provides a window on the world of knowledge and is going out to where its users are. The unique selling propositions developed by libraries challenge old paradigms. Some phrased used are: We link people with information; Information, innovation, service; Educate! Inform! Promote!; Libraries are changing and dynamic places; Libraries are places of opportunity; Libraries bring you the world. The British Library ${ }^{19}$ has taken as its slogan The World's Knowledge. OCLC's Worldcat ${ }^{20}$ describes itself as Window to the world's libraries and uses a magnifying glass and Find it in as part of its promotional strategies. The Shanghai Library uses the phrase To help navigate knowledge and stimulate wisdom through excellent service and sincere cooperation ${ }^{21}$.

\section{Promotional Strategies}

The traditional services of libraries are not always well known. Most surveys of library use find that few users are aware of existing services offered. It is also extremely difficult to inform users of new services as they become available. Communicating what libraries do has always been difficult and as remote use increases, new strategies are required. All kinds of ideas are provided on various promotional strategies which libraries might adopt. The possibilities are limited only by one's own imagination. Libraries and librarians themselves must look the part and make an impression. Seminars, open houses, newsletters are all possibilities to be used. Incentives for library use or attendance at special programs can be provided. Many libraries produce bookmarks, flyers, newsletters and various hand-outs. These may be general or targeted at a specific level or type of use, or to a specific use. They may be produced at a time when changes are being made, particularly when new services are provided. The preparation of a press release which is provided to press sources known to be supportive of library endeavours will ensure that the appropriate message is told, and not necessarily the message which a hurried or ill-informed journalist might prepare. Most library suppliers and publishers produce publications and assistance in promotional strategies $^{22}$.

Employing professionals to write articles either for in-house use or external use will help ensure effective communication. Word of mouth communication about good service is extremely effective. Most libraries are part of larger organizations. Associating the library with all outreach and promotional activities of the parent organisation will ensure that the library is talked about and its services publicised. Open days, specialist seminars, receptions, exhibitions are all promotional opportunities. Giveaways and memorabilia (e.g. cups, pens, library bags, and sweets), tours, and book clubs are various approaches used. Some libraries have developed specific marketing or promotional plans which clearly outline what is done. Some of these libraries also evaluate their activities. Most business for companies comes from its repeat customers. Good customers are like fine antique china and should be treated as such. Libraries could do more to stay in touch with their clients and ensure repeat business. All complaints should be responded to, providing explanations, apologies where necessary, and rectification of any difficulties.

Friends groups are also used for promotional purposes. All successes should be publicised within the communities served and any and every occasion can be celebrated. Clients can be used both as tour guides and assistants to help provide a reality check in promotion and client recommendations have been used by successful business organizations for many years. The presentation of conference papers and the publication of articles in professional journals of various kinds, not just librarianship and the use of local newspapers and newsletters are also useful strategies. Key messages and stories aimed at the readership must be presented - not just what librarians think users need to know. Fine notices and date due slips can be used to communicate promotional messages. Exhibitions and displays also demonstrate library products 
and services. Use media techniques - get out and about and become involved in the community being served. Follow up on all contacts made and write letters particularly thank you ones. Plan ahead and on every occasion, work the room. Blogs ${ }^{23}$ and emails are being used as successful promotional strategies although many library users have become desensitized to email messages. Observe what other libraries and successful organizations do - and steal good ideas shamelessly.

\section{The@yourlibrary campaign}

Perhaps the most significant library promotional strategy developed has been the @your library theme introduced by the American Library Association and also adopted by the International Federation of Library Associations ${ }^{24}$. The program is intended to increase awareness and support for libraries and to update the image of libraries and librarians for the $21^{\text {st }}$ century. It is also intended to increase library usage and funding, and to bring renewed energy to the promotion of libraries and library services. Many useful ideas and tools are provided, ranging from slogans to ideas about internet use and PowerPoint presentations to help all kinds of libraries in reaching their intended or target audiences.

There are mistakes to avoid in promoting libraries. Do not over-promise and under-deliver. Libraries must ensure that they can deliver what they say they will. It is also important to be honest, always, and not to ignore difficulties or problems. In promoting the library, one must be sincere and genuine with people. Promotional activities involve marketing relationships as well as the library. There is no need to apologize unnecessarily but if mistakes are made, they must be admitted. Excuses will not do. The promotional journey can be slow at times and success may take time.

\section{The Library Website}

Most business organisations have learned that the website is a significant marketing and promotional tool. Advertising on the internet now exceeds advertising in other media. Libraries who were the first to develop websites have been slow to learn from their commercial colleagues when it comes to the use of the library website as a promotional tool. In examining library websites, it is difficult to find significant synergies. Some libraries design their websites around different types of user. Key clients can be targeted. Some libraries design their websites around the collections or services. Websites frequently differentiate between For and About. Some websites appear to have no clear focus for their design and presentation of either information or access to information. There is an enormous opportunity to study the use of library websites and to learn from that use. Focus groups with different types of users will demonstrate different requirements in use. Some studies have been made of website use ${ }^{25}$. These studies show that users want simple words to be used which explain the terms and meanings clearly and succinctly. Users experienced difficulty finding "books" when terms like resources were used. The use of the term database without any indication that these databases contained journal articles also challenged users. Terms for which users indicated preferences were Research finder, Getting Started, Research Pathfinders, Beginning Research, Where to Start, Researching? Start Here. The old fashioned term "Catalogue" appeared to be more popular than some of the catchy names libraries have used to refer to their catalogues. Clarity, conciseness, consistent layout and minimal graphics remain major requirements in websites. The website is both a source of access and a promotional tool for the Library and should be designed and presented as such.

\section{The Role of the Librarian}

Librarians have traditionally been intermediaries guiding users to information. The nature of the work done by librarian intermediaries has changed. The librarian has moved from an observer in the wings to an active partner as librarians guide users to appropriate information resources and advise on their use. Librarians are sometimes now described as information consultants, knowledge brokers or knowledge managers. As librarians market and promote their services, new skills and knowledge are required. Librarians must be good at listening and responding. All library staff are involved with client service delivery and all staff require training in customer service - and it goes further than saying Have a nice day. The familiar saying holds true - I do not care how much you know until I know how much you care. Part of the service strategy is to reduce the number of service points and therefore people with whom each user is involved - being directed from one spot to another can be very frustrating. Recruiting staff that are highly service-oriented is paramount. Librarians have all too frequently been characterised as fearsome gorgons and guards who occasionally and begrudgingly assist users - rigid enforcers of rules, more interested in 
themselves than the users. Bright, cheerful friendly professionals providing quality service to all are required. Sorry, glad, sure is a training strategy which has been used at McGill University Library. I am sorry you have had a problem with our service today. I am glad you have told me about it. I am sure we can do something to fix the situation. Liaison librarians who are attached to various categories of library users are very important as personal promoters of library services. Liaison librarians can be librarians on location - situated with groups of users they serve. Librarians need to gain new skills and must be able to teach information literacy programs. In a time of high tech, high touch is also important. Library users still require and appreciate real help from real people - and they want to find those people easily.

New roles require different attitudes, skills and knowledge. A concern for detail and an orderly organized approach will not be enough. The focus must be on the user and the needs of the user, the environment, the nature of information and the workplace itself. Librarians in the new context must to be able to:

- Implement innovative responses in a timely and positive manner

- Meet users where they are and not wait for users to come to them

- Change their own behaviour to meet changes in client behaviour.

- Focus on the user's point of view, not the librarian's point of view

- Provide services at times and in places which are convenient to users $(24 \times 7)$.

- Understand user needs for personalization and categorization

- Support self-service as well as service in person and online, including online chat.

- Provide the "library to go", visiting users where they

- Adopt marketing approaches to information service delivery

- Train themselves and others

- Collaborate and work in partnership with others.

- Provide information via web pages, wikis, blogs or online gateways

- Demonstrate agility, flexibility and an ability to innovate

\section{Conclusion}

Libraries are operating in a rapidly changing environment. New promotional and marketing strategies are required to ensure that libraries continue to reach their users and maintain the relevance of their service offerings. Librarians themselves must also change to gain new skills, attitudes and knowledge to operate effectively in this changing environment so that user needs are understood and met.

\footnotetext{
${ }^{1}$ Public Library of Science. http://www.plos.org/ Viewed $28^{\text {th }}$ October, 2006.

${ }_{2}^{2}$ BioMedCetral: the open access publisher. http://www.biomedcentral.com/ Viewed $28^{\text {th }}$ October, 2006.

${ }^{3}$ Oxford Journals. Oxford Open. http://www.oxfordjournals.org/oxfordopen/.

${ }^{4}$ Blackwell Publishing. Online Open. http://www.blackwellpublishing.com/static/onlineopen.asp. Viewed 28th October, 2006.

${ }^{5}$ http://www.flickr.com. Viewed $28^{\text {th }}$ October, 2006.

${ }^{6}$ YouTube broadcast yourself. Recently purchased by Google. http://www.youtube.com/. Viewed $28^{\text {th }}$ October, 2006.

${ }^{7}$ The Sony Reader. http://www.learningcenter.sony.us/assets/pa/prs/index.html?DCMP=Reader_Google\&HQS=sony_ebook. Viewed $28^{\text {th }}$ October, 2006.

${ }^{8}$ The end of print. www.cbc.ca/theend. Viewed 13th August, 2006.

${ }^{9}$ For example, the paper by Peter Nicholson, President, Council of Canadian Academies, "The changing nature of intellectual authority" Presented at the $148^{\text {th }}$ meeting of the Association of Research Libraries, Ottawa, Canada, 2006. http://www.arl.org/arl/proceedings/148/nicholson.html. Viewed 28th October, 2006. ${ }^{10}$ A Wikimedia project. http://www.wikiversity.org/. Viewed $28^{\text {th }}$ October, 2006.

${ }^{11}$ OCLC. Environmental scan: pattern recognition (2003). http://www.oclc.org/reports/escan/. Viewed $28^{\text {th }}$ October, 2006.

${ }^{12}$ OCLC. Perceptions of libraries and information resources. 2005 http://www.oclc.org/reports/2005perceptions.htm
} 
${ }^{13}$ Various reports testify to the changes. One site of interest is http://www.youthography.com/aboutus/press/newsletter.aspx. Viewed 28th October, 2006. LAC (Library and Archives Canada) hosted a seminar examining some of the implications of new use and this is reported at a series of meetings entitled: Toward a Canadian Digital Information Strategy. The second meeting addressed some of the issues: Toward a Content Strategy. http://www.collectionscanada.ca/cdis/012033903-e.html\#a. Viewed $28^{\text {th }}$ October, 2006

${ }^{14}$ Pew/Internet, American Life \& Internet Project. http://www.pewinternet.org/index.asp. Various reports. Viewed 28th October, 2006

${ }^{15}$ Naomi S. Baron "Why read when you can google? Search engines_abound:: our literate society is endangered by the quick satisfaction of the internet "The Gazette, Montreal. December 4, 2005, p.A15

${ }^{16}$ S.R. Ranganathan. The five laws of library science. $2^{\text {nd }}$ ed. (Bombay: Asia Publishing House, 1963)

${ }^{17}$ For example: Marketing Library and Information Services: International Perspectives, Edited on behalf of IFLA by Dinesh K. Gupta , Christie Koontz, Angels Massisimo and Réjean Savard. (Munchen: Saur, 2006)

18 . Michael Stephens. "The iPod experiments." Library Journal. April $15^{\text {th }}, 2005$

http://www.libraryjournal.com/article/CA515808.html. Viewed 20th May, 2006

${ }^{19}$ http://www.bl.uk/ Viewed $28^{\text {th }}$ October, 2006

${ }^{20} \mathrm{http} / / /$ www.oclc.org/worldcat/ Viewed $28^{\text {th }}$ October, 2006

${ }^{21}$ http://www.library.sh.cn/new-eng/. Viewed $28^{\text {th }}$ October, 2006

${ }^{22}$ Thomson Learning provides marketing ideas and publications. http://www.galegroup.com/free _resources/marketing/find_yourself/. Viewed $28^{\text {th }}$ October, 2006

${ }^{23}$ Darlene Fichter. "Why and how to use blogs to promote your libray's services MLS Markting Library services vol. 17, no.6, Nov/Dec.2003. http://www.infotoday.com/MLS/novo3/fichter.shtml. Viewed 7th August, 2006

${ }^{24}$ American Library Association @your library.

http://www.ala.org/ala/pio/campaign/campaignamericas.htm. Viewed $20^{\text {th }}$ May, 2006

${ }^{25}$ Library terms users evaluated in usability tests and other studies. http://www.jkup.net/terms-studies.html. Viewed 28th October, 2006 